\title{
Mardin Evlerinde Mihrabiye Formlu İki Niş
}

\author{
İbrahim Halil KARABULUT ${ }^{1}$
}

Atıf/C: Karabulut, İ. H. (2021). Mardin Evlerinde Mihrabiye Formlu İki Niş. Artuklu İnsan ve Toplum Bilim Dergisi, 6(2), 88-108.

Öz

Mardin kent dokusu arazi şartlarının kullanılabilirliği ölçüsünde inşa edilmiş yapılardan oluşmaktadır. Yapılar arasında, kentte yaşayan tüm zümrelere ait özel mekânların varlığı da baskın şekilde görülmektedir. Evler, topografyanın zorluklarına rağmen kent dokusu içerisine ihtiyaçlar doğrultusunda kendiliğinden şekillenen bir düzene göre yerleşmiştir. Kent dokusunun belirleyici unsuru evler 18. ve 19. yüzyılda geleneksel mimari tasarımın ürünü olarak şekillenmiştir. Toplumsal sınıf farkına ait referansların belirgin halde yansıtıldığı evlerde özellikle Başoda olarak kullanılan özel odalar plan şemalarında dikkat çekmektedir. Başoda tasarımına verilen önem oda içerisinde yer alan ve süslemeleri ile dikkat çeken mihrabiye formlu nişlerde belirgin şekilde görülmektedir. Mihrabiye formlu nişler, tasarım ve süsleme özellikleri açısından konut içi süsleme geleneğinin bir parçasını oluşturmaktadır. Mardin kent dokusunu oluşturan evlerin ikisinde yer alan mihrabiye formlu nişler bu kapsamda incelenmiştir. Çalışmayı destekleyen geleneksel konut mimarisindeki eşdeğer formlara kısaca değinilmiştir. Ardından Mardin Evlerinde bulunan ve incelemeye konu olan mihrabiye formlu nişlere sahip evlerin mimari özellikleri aktarılmıştır. Son olarak nişler tanıtılmış ve yapılan değerlendirmeler ile mihrabiye formlu nişlerin konut içi süsleme geleneğinde yerel özellikle sahip Mardin evlerine ait özgün tasarımlar olduğu sonucuna ulaşılmıştır.

Anahtar Kelimeler: Mardin Evleri, Başoda, Mihrabiye, Niş, Süsleme

\footnotetext{
1 İbrahim Halil Karabulut, Yüksek Lisans Öğrencisi, Mardin Artuklu Üniversitesi, ibrahim_karabulut002@hotmail.com 0000-0002-4831-9446

Geliş/Received: 17 Kasım 2021, Kabul/Accepted: 20 Aralık 2021
} 


\title{
Two Niches with Mihrabiye Forms in Mardin Houses
}

\author{
İbrahim Halil KARABULUT
}

Citation/C: Karabulut, İ. H. (2021). Two Niches with Mihrabiye Forms in Mardin Houses. Artuklu Human and Social Science Journal, 6(2), 88-108.

\begin{abstract}
The urban fabric of Mardin, which consists of structures built in accordance with the availability of land conditions. The existence of private spaces belonging to all groups living in the city is also dominant among the buildings. Although the houses have difficulties of topography, they are settled according to a self-shaping order in acoordance with the needs within the urban fabric. Houses, the defining element of the urban fabric, were shaped as a product of traditional architectural desing in the 18th and 19th centruries. In the houses where the references of social class difference are clearly reflected, especially the special rooms used as the headroom draw attention in the plan schemes. The importance given to the design of the main room can be clearly seen in the niches in the form of the mihrabiye, which attracts attention with their decorations. Mihrabiye-shaped niches, in terms of design and decoration features, it forms a part of the tradition of interior decoration. The niches in the form of mihrabiye in two of the houses that make up the urban fabric of Mardin were examined in this context. Equivalent forms in traditional residential architecture supporting the sduty are briefly mentioned. Then, architectural features of the houses with niches in the from of mihrabiye, wich are located in the Mardin houses and are the subject of the examination, are conveyed. Finally, niches were introduced and it was concluded that niches in the form of mihrabiye are original desings belonging to Mardin houses, which have a local characteristic in the tradition of interior decoration.
\end{abstract}

Keywords: Mardin Houses, Main Room, Mihrabiye, Niche, Ornament 


\section{GÍRiș}

Mezopotamya'nın geniş düzlüklerinden sonraki önemli yükseltinin başlangıcı sayılabilecek konumu dolayısı ile tarih boyunca önemli bir kavşak noktasında yer alan Mardin, farklı kültürlerin etkileşim alanı olmuştur. Sosyal hayatın her alanına yansıyan bu kültürel çeşitlilik kent kimliğinin oluşmasına da katkı sağlamıştır.

Bir kale yerleşimi olarak ilk kez Roma devrinde tarih sahnesinde adının anıldığı şehir stratejik konumu dolayısı ile zamanla ciddi olarak yerleşim alanına dönmüştür. Özellikle 7. yüzyılda başlayan İslam fetihlerinin ardından 11 yüzyılda Artuklu hâkimiyetinin sürdüğü üç yüz yılı aşkın süreçte başkent olarak Mardin (Artuk,1944:8) yerleşimi kale içerisinden dağ yamacına doğru genişleme göstermiştir. Bu süreçte inşa edilen abidevi yapılar ile kentin bugün görünür olan kimliğine o dönemde kavuştuğu söylenebilir. Artuklu hâkimiyeti kentte kültürel etkileşimin mimari alana yansıdığı ve geleneksel mimarinin kent ile bütünleştiği dönem olarak anılmaktadır (Resim 1).

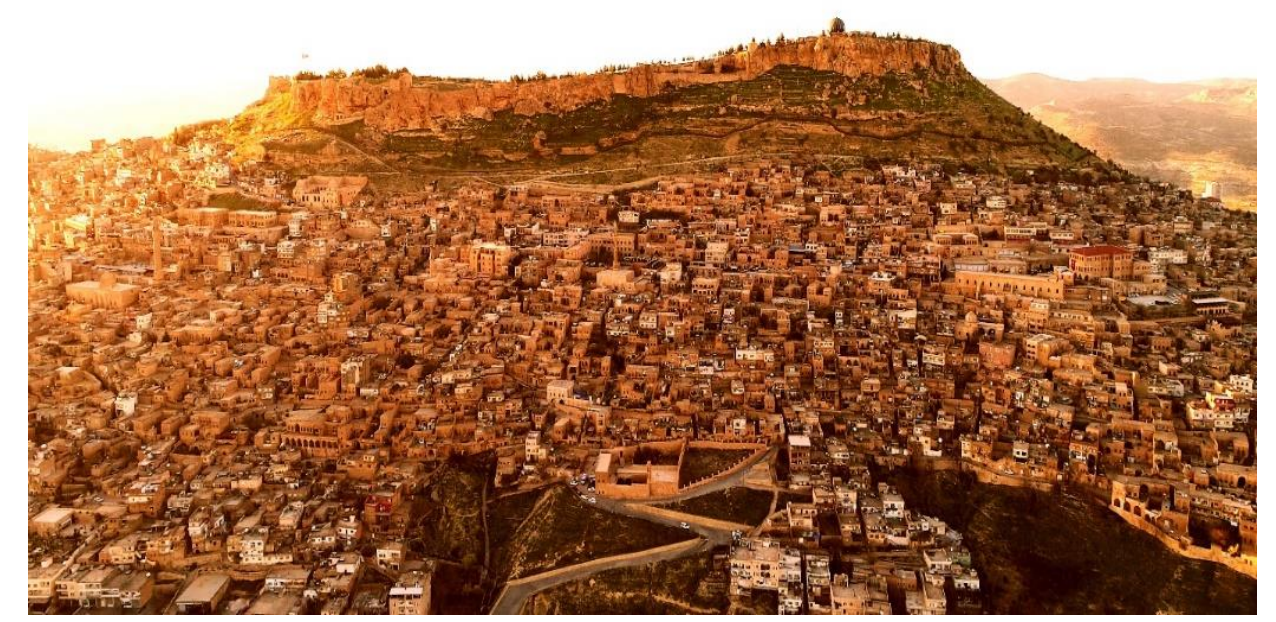

Resim 1: Mardin Genel görünüm (http://www.mardin.gov.tr/yeni-mardin-evleri)

Artuklu sonrası dönemde Akkoyun ve Karakoyunlu ile Osmanlı hâkimiyet süreçlerinde kent kimliği özgünlüğünü büyük ölçüde korumuştur (Aliyeva,2007: 267). Dă̆ yamacına yayılan yerleşim bu dönemlerde daha geniş bir alana yayılmıştır. Kültürel çeşitliliğin yoğun olduğu, çeşitli etnik ve dini kimliklerin varlığını sürdürdüğü şehirde, mahalle sayısı sürekli olarak artmıştır (Göyünç,1997: 97). Bu mahalleler şehrin de kimliğini oluşturan ana unsurların isimleri ile anılmaya başlanmıştır.

Sahip olduğu stratejik önemi dolayısı ile daimi bir doğal savunma alanı olan kaleden yamaca doğru genişleyen yerleşim, kültürel etkileşimin mimari alana yansımasına katkı sağlamıştır. Sivil mimari, bölgenin mimari geleneklerinden ve kullanılan malzemeden etkilenerek özgünlük oluşturmuştur (Çerme,2000: 52).

Anadolu evinde plan şemasını sofa ve eyvan şekillendirmektedir (Eldem,1961:12). $\mathrm{Bu}$ şekilde oluşan ev plan tiplerinde, yaşam alanlarının bölünüp-çoğalabilme imkânları 
mevcut olmuştur. Mardin evlerinin bir özelliği de plan şemalarının dönüşümü ile yeni yaşam birimlerinin yaratılması durumudur (Alioğlu,1989: 117)

Mardin konut mimarisinde plan anlayışının şekillenmesi, coğrafi etken ve iklim koşullarının etkisi olmuştur. Plan anlayışının şekillenmesi bütünüyle arazi şartlarının elverişliliği durumuna göre olmuştur. Evlerin ilk inşa edildiği süreçlerde tek katlı ve kullanım amacına uygunluk öne çıkmıştır. Arazi eğiminin ve kısıtlı inşa alanın varlığı evlerde birden fazla kat çıkma seçeneğini ortaya çıkarmıştır. 19. ve 19. yüzyıl itibari ile Mardin evleri plan şemaları genel olarak biçimlenmiştir. Zemin üzerine inşa edilen ilk katlarda şekillenen plan çeşitliliği oldukça fazla olmasına rağmen, ' $L$ ' ve ' $U$ ' plan tipleri öne çıkmaktadır.

Başoda, Mardin evlerinde plan tipinin şekillenmesinde asıl rolü üstlenmiştir. Özellikle coğrafi ve iklimsel yakınlık ve manzara kültürünün varlığı ile başodanın düzen kurgusunda Kuzey Suriye etkisinin varlı̆̆ 1 hissedilmektedir (Akın,1989: 25;Alioğlu,1989:113). Başoda merkezindeki nişler, dini mimaride görülen mihrap ve anıtsal yapılardaki taçkapı ana girişi yan yüzlerine hareketlilik sağlamak için kullanılan mihrabiyelere (Çakmak,2001: 166) benzerlikleri ile özel bir konumda yer almaktadır (Resim 2). Sadece estetik bir öğe olarak odanın süsleme programının merkezinde bulunan bu nişler taçkapılardaki mihrabiyelerin form ve bezeme açısından gelişme göstermiş ve ibadet yapılarında görülen mihrap formları boyutuna ulaşmıştır. Mihrabiye formu ile anıtsal görünüme ulaşan bu nişler konut içinde nadiren görülebilen örnekler arasındadır. Mardin evlerinin inşa geleneğinin bir parçası olarak kabul görmüş mihrabiye formlu niş örnekleri bu bağlamda dikkat çekicidir.

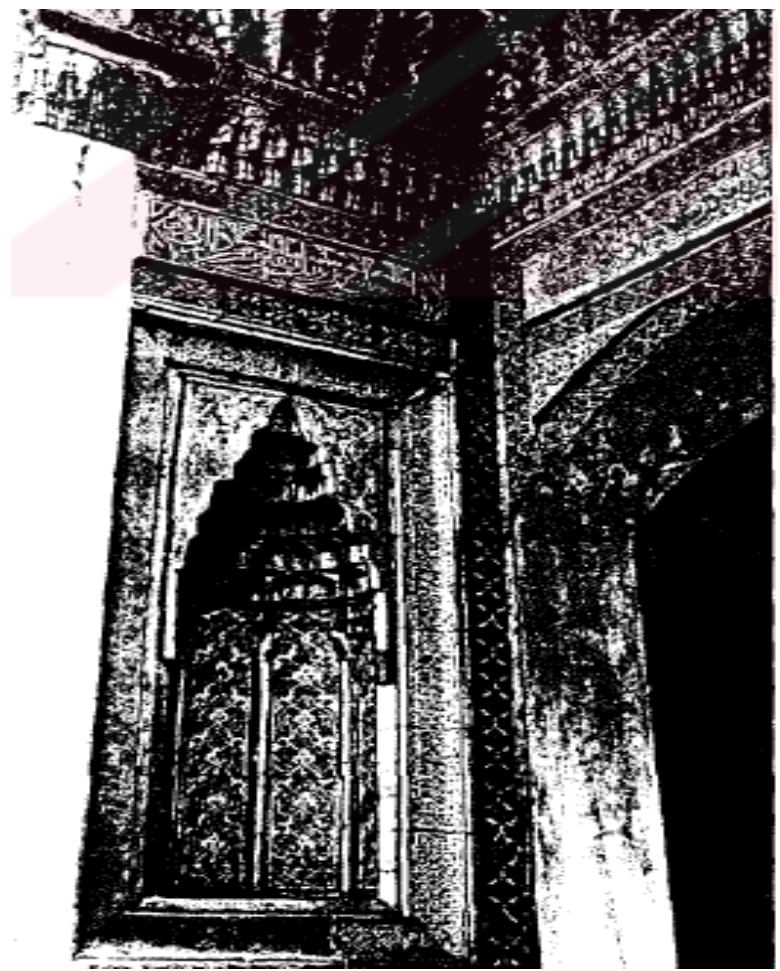

Resim 2: Bursa Yeşil Türbe Taçkapısı Mihrabiye (Çakmak,2001) 
Oda içerisinde tüm duvarlar üzerinde genel olarak yer alan ve işlevsellik kazandırılan nişler, başoda içerisinde özel ve farklı bir anlama bürünmüştür. Kimlik, statü göstergesi olarak odanın tasarımında etkili süsleme programı en çok nişler üzerinde uygulanmıştır. Nişlere ait özellikle kemer yayları ile kandil nişleri süsleme programının bir parçası olarak bezenmiştir (Karabulut,2019:92). Odanın genelde güvey duvarı üzerinde yer alan, zengin bir süsleme programına sahip nişler, abidevi özellikler ile benzer formlar içerisinde de bağımsız niteliklere sahiptir.

Oda içerisinde yer alan diğer işlevsel diğer nişlerden bağımsız gibi görünen ancak anıtsallığı ile mihrap formuna kavuşmuş görünümleri ile mihrabiye formlu nişler, malzeme ve teknik olarak Mardin'e ait geleneksel ögeler barındırmaktadır. Süsleme programının içerdiği detaylar ise bölgenin geleneksel süsleme anlayışını ve çeşitliliğini yansıtmaktadır.

Çalışmada Mardin evlerinde başoda özelindeki biçimsel ve estetik değerler ile ön plana çıkan Mihrabiye formuna sahip iki niş incelenmiştir. Nişlerin form ve süsleme özellikleri ile Mardin evlerindeki konut içi süsleme geleneğindeki önemine vurgu yapılmıştır. Bu kapsamda çalışmanın amacı mihrabiye formlu nişlerin anıtsal bir tasarımla Mardin evlerinin ayrılmaz parçası olduğu üzerinde durulmuştur. Mardin Evleri sanat tarihi çalışmalarında henüz kapsamlı olarak incelenmemiştir. Çalışmanın var olan eksikliği kısmen de olsa doldurması ve yapılacak yeni araştırmalara katkı sunması amacını da taşımaktadır.

\section{Geleneksel Konut Mimarisinde Mihrabiye Formlu Nişler}

Konut mimarisinde Anadolu evi kendi mekân arayışında tekdüze bir yol izlememiştir. Coğrafyanın ve kültürel etkileşimin tüm boyutlarının varlığını hissettirdiği konutlarda plan şemaları ve yaşam birimleri değişim ve dönüşüme uğramıştır. Türk evi bu bağlamda Anadolu'da kendi özgün karakterini bulmuş ve etkileşim halinde olduğu kültürlerden beslenerek Avrupa'ya açılmıştır (Eldem,1961:11).

Türk evinde başodalar, evin bütünü içerisinde kendi özelinde kendi birimleri olan alanlar olmuştur (Küçükerman,1985:63). Odaların oluşum süreçlerinde toplumsal yaşantının ve geleneklerin etkisi hissedilmektedir. Bu oluşum süreçleri bölgelere ve konut mimarisindeki etkileşim unsurlarının varlığına göre değişmiştir. Mevcut odanın konumu, taşıyıcı ögeleri, aydınlatma ve ısınma sistemleri ile cephe düzenlerinde bölge ve kültürel etki hissedilmektedir.

Konut mimarisinde oda daha gösterişli ve özenli ciddi bir gelişim göstermiştir. Selamlık olarak adlandırılan misafir ağırlama odası ev planı içerisinde daha özel bir konuma ulaşmıştır. Selamlık bölümü, evin diğer birimlerinden daha düzenli olarak öne çıkmıştır. Anadolu'daki selamlık bey konaklarında başodaya (Sözen-Tanyeli, 2011:47) dönüşmüş̧ür.

Türk ev geleneğinde Selamlık olarak değerlendirilen ve diğer odalardan daha özenli ve gösterişli olan oda Mardin evlerinde başodadır. Oda içerisinde yer alan tezyinat bu alanın evin diğer tüm birimlerinden tasarım açısından farkını göstermektedir. Anadolu coğrafyasında çeşitli bölgelerdeki konut içlerinde daimi olarak böyle bir mekânın varlı̆̆ 1 ve içerisindeki süsleme ögeleri dikkat çekmektedir. 
Oda tasarımlarımın ayrılmaz bir parçası nişlerdir. Evin ihtiyaçları karşılayacak şekilde cephe duvarları üzerinde yer alan nişler, kullanım amaçlı dolap, yüklük ve kandillik gibi işlevsel özelikleri barındırmaktadır. Farklı kullanım amacına hizmet eden bu açıklıklar ölçü ve şekil olarak birbirinden farklı niteliklerde tasarlanmışlardır. Evin en büyük ve geniş odasında yine aynı amaçla yer alan nişler statü ve kimlik göstergesi olarak daha estetik bir görünüme ulaşmıştır.

Konut mimarisinde bölgesel farklılıkların da şekillendirdiği niş kullanımı genellikle yarım yuvarlak bir açıklıktan ibarettir. İşlevsellik kazandırılan yarım yuvarlak açıklık bölgesel mimari etkilerin şekillendirmesi ile zamanla çeşitli ve zengin süsleme programının uygulandığ1 estetik bir unsura dönüşmüştür. Mardin evlerinde kullanılan nişlerde ise bu dönüşüm daha anıtsal bir görünüme bürünerek dini mimaride kullanılan mihrap formunun özelliklerini almıştır.

Mihrap formuna dönüşen nişlerin anıtsallığı, odanın bütününde görülen bezeme programının merkezinde yer almıştır. Süsleme programının ayrı bir değerlendirmeye tabi olacağı oda tasarımlarında mihrabiye formlu nişler ile benzer formlar daima yer almıştır. $\mathrm{Bu}$ formlar farklı bölgelerdeki evlerde dekorasyonun bir parçası olarak fazla derin olmayan boyutları farklılık gösteren bir niş şeklinde başodanın merkezinde bulunmaktadır. Anadolu konut mimarisinde üç şehirdeki evlerde bulunan benzer örnekleri ile mihraba benzeyen bu nişler, Şerbetlik, Aynalık, Cennetlik gibi isimler ile anılmaktadırlar.

Mihrabiye formlu nişlerin görüldüğü kentlerden olan Diyarbakır'da da evler iklim koşullarının şekillendirmiş olduğu plan şemalarına sahiptir. Genel olarak tek katlı inşa edilmiş yapılar bir avlu etrafında sıralı mekânlardan oluşmaktadır (Erginbaş, 1954:7; Tuncer,2015:32).

Diyarbakır evlerinde süsleme en çok evlerin dış cephelerinde görülmektedir (Baş,2010:312). Oda içlerinde en yoğun süslemeler nişlerde karşımıza çıkar. Malzeme olarak daha çok tercih edilen bazalt taşının tekdüzeliğini kırmak için cas $^{2}$ kireç harcı ile yapılan süslemeler kullanılmıştır. Nişler oda içlerinde kapı girişi yanındaki duvarda üç dilimli sivri kemerler ile yer almaktadır. Daha çok dış cephede görülen pencere nişlerinin bir benzeri olan başoda nişleri fazla derin olmayacak şekilde tasarlanmıştır. Derinlik olarak yuvarlak bir girintiden ziyade dikdörtgen ve düzgün bir görüntü sergilemektedirler. Özellikle kemer yayı üzerlerinde yer alan ve siyah bazalt taşı yanında beyaz cas süslemeler ağırlıklı bitkisel motifli süslemelerdir (Resim 3). Vazolardan çıkan çiçek dalları ve soyut düzenlemeler süsleme programlarını oluşturmaktadır (Baş, 2010:314).

\footnotetext{
${ }^{2}$ Kireç harcı ile yapılan bir süsleme tekniği. Killi kireç taşının belli sıcaklılarda özel fırınlarda pişirilmesi ile daha sonra ögütülmesi sonucu elde edilen malzeme. (Tuncer, O. C. 2015: 56-59).
} 


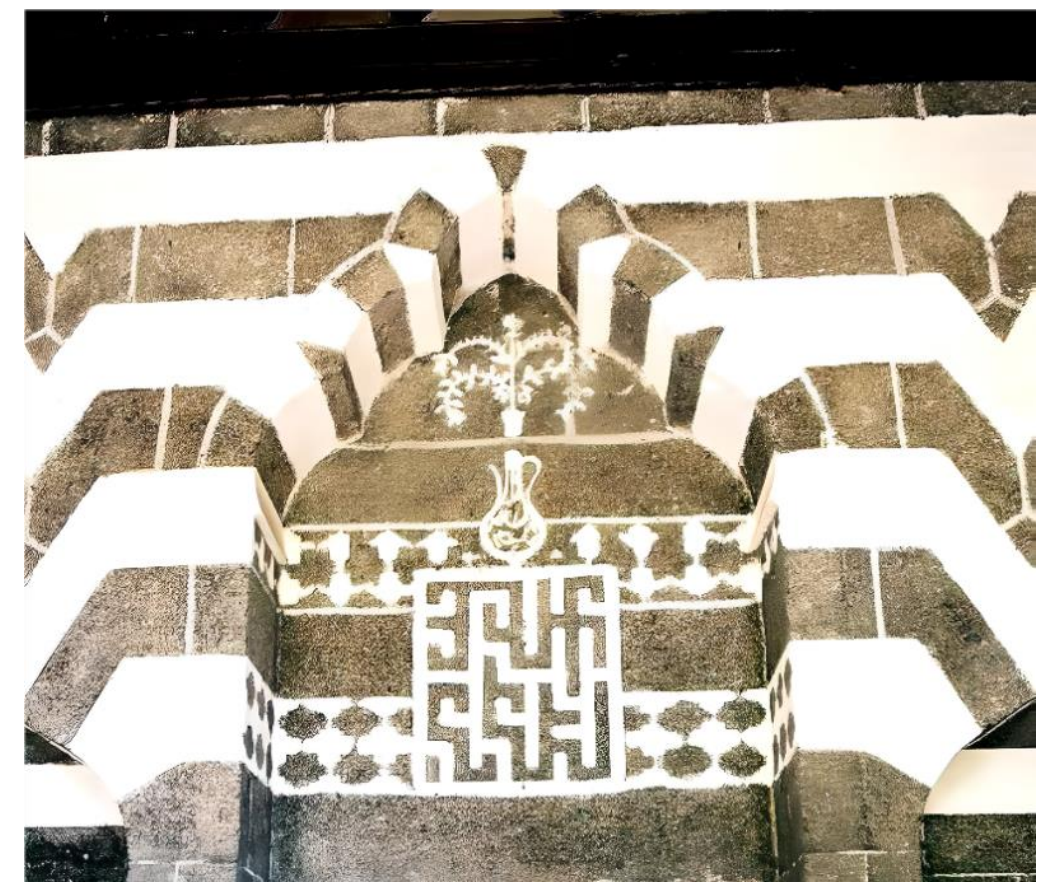

Resim 3: Cahit Sıktı Tarancı Evi Oda Niş ve Cas Süslemeler Niş (Baş,2010)

Diyarbakır merkezde ve Hazro ilçesinde Bey konaklarında oda içlerindeki kimi dolap nişleri ziyadesi ile zengin bir bezeme programına sahiptirler. Bu tarz dolap nişlerinin alçı kalıplama tekniği ile yapılmış süslemeler birbirini tekrar eden çiçekler ve çelenk görünümlü bitkisel düzenlemelerdir. Niş derinliği çoğu zaman mukarnas kavsara ile hareketlendirilmiştir. Her iki yanda görülen ince ve zarif sütunçeler nişlerin anıtsallığına dikkat çekmektedir. Bütünüyle alçı malzeme ile yapılmış nişler ve süsleme özellikleri daha orijinal özelliktedir (Tuncer,2015:62:Baş, 2010:315) (Resim 4-5).

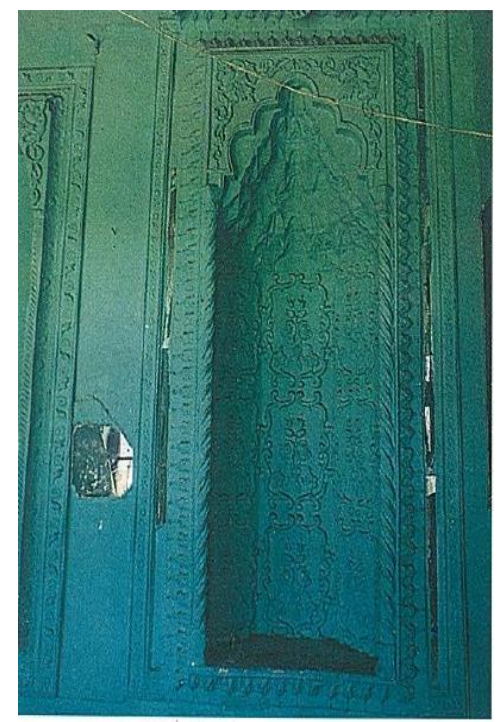

Resim 4:Diyarbakır Yiğit Ahmet Sok. Ev Nişi (Tuncer,2015)

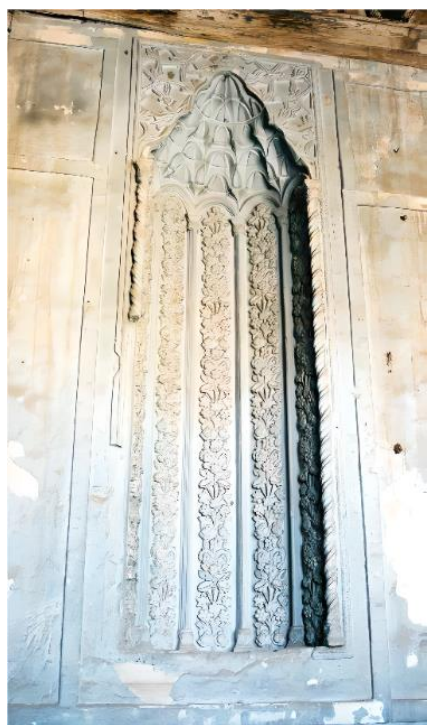

Resim5: Hazro Cemiloğlu Konağı Mihrabiye Niş (Baş,2010) 
Doğu Anadolu bölgesinde Erzurum evleri ise sofanın durumuna göre farklı plan tipleri ortaya çıkmıştır (Karpuz,1979:). Türk evinin genelinde olduğu gibi Erzurum evlerinde de başodanın varlığı evin genel planını şekillendirmiştir.

Erzurum evlerinde başoda içerisindeki süsleme programının yoğun olarak yer aldığı mihrabiye formlu nişler çiçeklik olarak adlandırılmaktadır. Genel olarak başoda giriş kapısının üzerindeki duvarda yer almaktadırlar. Çiçeklikler tasarım özelliklerine göre yuvarlak kemerli ve tekne tipi çiçeklikler olarak iki gruba ayrılmıştır (Sağlam, 2019:1148). Çoğunlukla ahşap ve alçı malzeme ile yapılmışlardır (Resim 6-7).

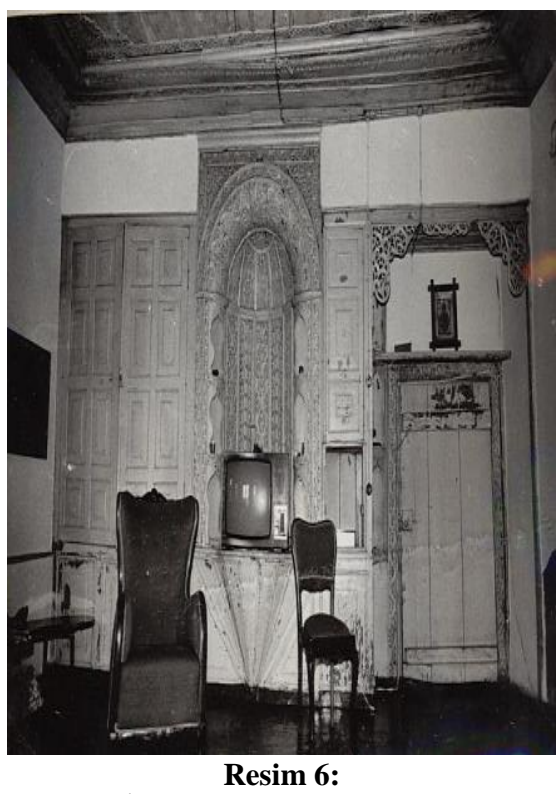

Erzurum İbrahimhakkığulları Evi Çiçeklik (Sağlam,2019)

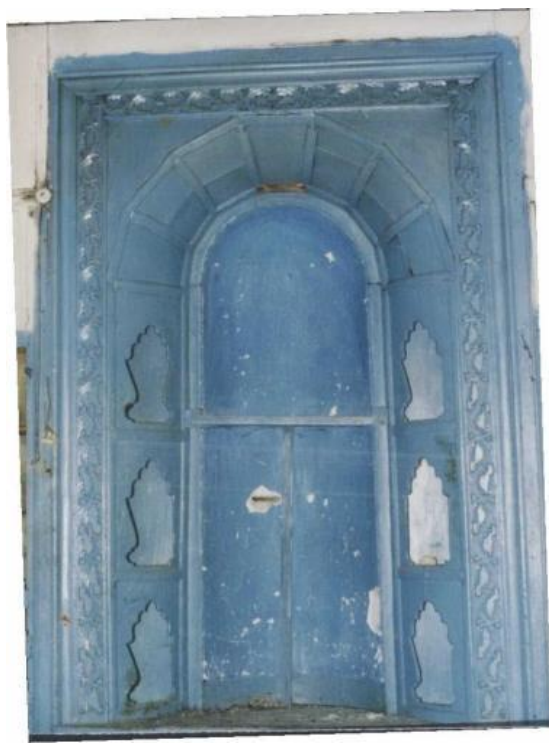

Resim 7:

Erzurum Faik Kumbasar Evi (Karpuz,1979)

Orta Anadolu'da, kültürel sürekliliğin etkisi ile biçimlenmiş Kayseri Talas evlerinin tasarım özellikleri dikkat çekicidir. Zaman içerisinde iç ve dış sofalı plan tipine evrilmiş olan evlerde sofalar, evin plan bütünlüğü tayin etmiştir. Fakat başoda kavramının genelleşmesi Talas evlerinde plan bütünlüğünü etkilemiştir (Korkut, 2019:37)

Çift girişleri bulunan Başodaların içerisindeki nişler, işlevsel ve görsel plan elemanları olarak tasarlanmışlardır. Özellikle oda merkezinde yer alan ve diğer nişlere nazaran daha büyük olan niş, batı veya doğu duvarında yer almaktadır. Başoda haricinde diğer oda içlerinde de yer alan nişler, ahşap dolap nişleri ile bir bütünlük oluşturacak şekilde tasarlanmıştır. Nişler gilve ismini alan küçük raflar ile bir bütün halinde görülmektedirler (İmamoğlu, 1992:154). Bu nişler dışa taşkın tabanlıkları ve S kıvrımlı öğeler ile desteklenmiştir. Başoda içerisindeki nişlerin daha sade bir anlayış ile ahşap malzemeden yapıldığ 1 görülmektedir (Ünlüdil, 2018:61). Sofa içerisindeki odalarda yer alan nişe ait süslemeler ise barok ve rokoko tarzındaki kalem işleridir. Niş içerisindeki süsleme unsurları yine barok ve rokoko tarzda kıvrımlı yapraklar, vazo içerisindeki çiçekler ve püsküllerdir (Resim 8-9). 


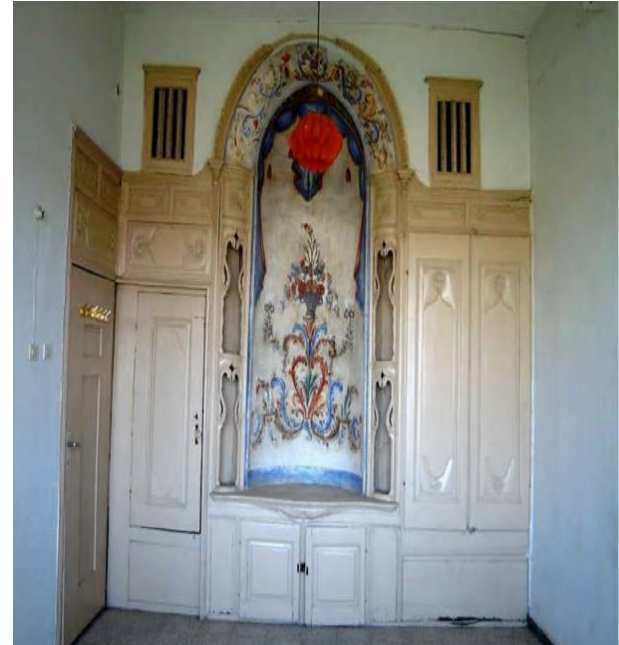

Resim 8: Talas Ali Kürtüncü Evi Şerbetlik (Korkut,2019)

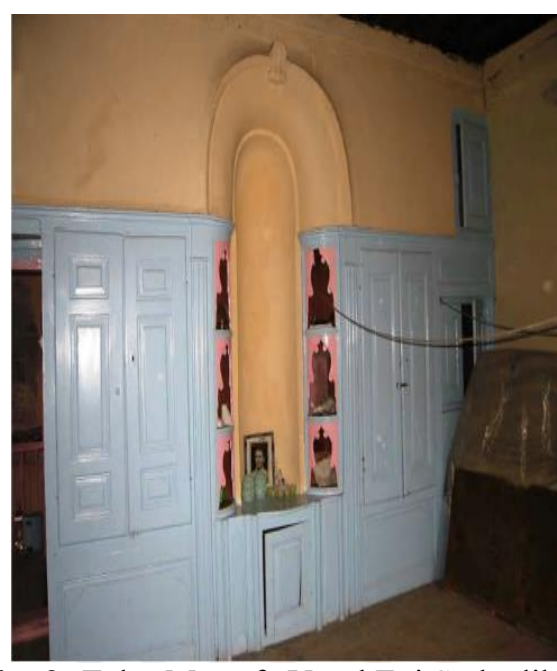

Resim 9: Talas Mustafa Vural Evi Şerbetlik (Ünlüdil,2019)

Araştırma kapsamına alınan Mihrabiye formlu nişlerin bulunduğu evler Mardin Çabuk mahallesinde yer almaktadır. Konutlar, farklı tarihlerde Mardin Müzesi tarafindan yapılan çalışmaları ile tescilli yapılar listesine eklenmiştir. İncelenen evlerin sadece biri daimi ikamet olarak kullanılmaktadır. Emel Balamur'a ait bu evde farklı katlarda iki aile ikamet etmektedir. Diğer ev ise tek bir mülk sahibine ait görünmektedir. Suphi Yertüm evi mülk sahipleri tarafından yazlık ikamet olarak kısmen kullanılmaktadır.

\section{Emel Balamur Evi}

\section{Genel Tanım}

Konut, Çabuk Mahallesinde 32. ada ve 18. parselde yer almaktadır. İki katlı kâgir ev statüsünde Mardin Müzesi tarafından yapılan çalışmalar ile tescilli yapılar listesine 2012 yılında alınmıştır. İkinci kat eyvan tavanında bulunan alçı kabartma süsleme arasında 1898 tarihi okunmaktadır. Bunun haricinde yapım tarihine ait başka bir kitabe veya belge bulunmadığından yapının inşa tarihi olarak esas alınmıştır.

Arazi şartlarına uygun olacak şekilde inşa edilmiş yapıya, alt ve üst sokak kotlarında eve geçişi kolaylaştırmak için kuzey ve güney cephelerde iki adet giriş eklenmiştir. $\mathrm{Bu}$ girişlerden güney cephede yer alan ana giriş kapısı statüsündedir.

Yapı inşa edildiği tarihten itibaren asıl amacına uygun olarak kullanılmaya devam etmektedir. İki katlı yapının her katı farklı aileler tarafından kullanılmaktadır. Araştırma konusunu oluşturan Mihrabiye formlu nişin yer aldığı başoda, evin ikinci katında bulunan terasın doğu bölümünde yer almaktadır.

Yapının ikinci katına erişim kuzeybatıda yer alan dar sokak içerisinde gösterişsiz bir açıklık ile sağlanmaktadır. Güneye doğru genişleyip uzanmış terasın kuzeyinde yaşam alanları 'L' plan şemasını oluşturacak şekilde sıralanmıştır (Şekil 1) (Resim 10). 

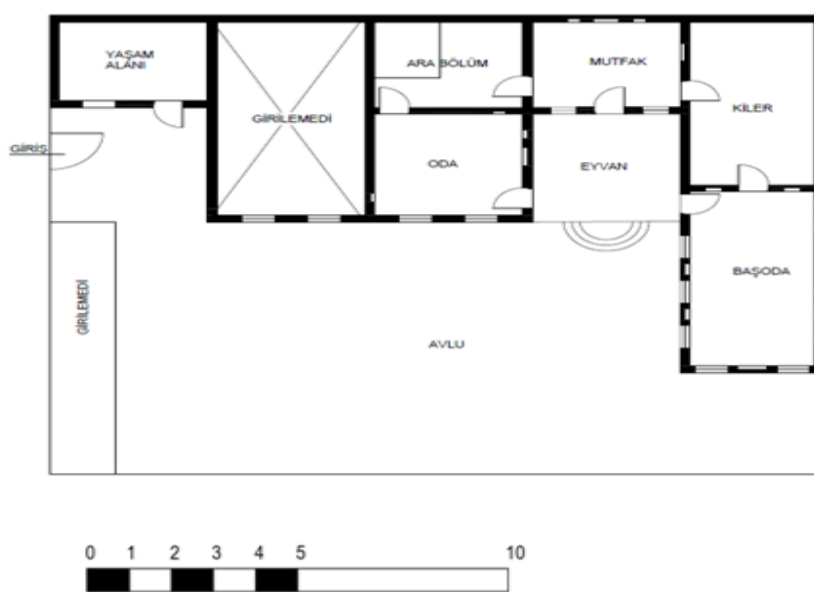

Şekil 1: Emel Balamur Evi Birinci Kat Planı (Karabulut,2019)

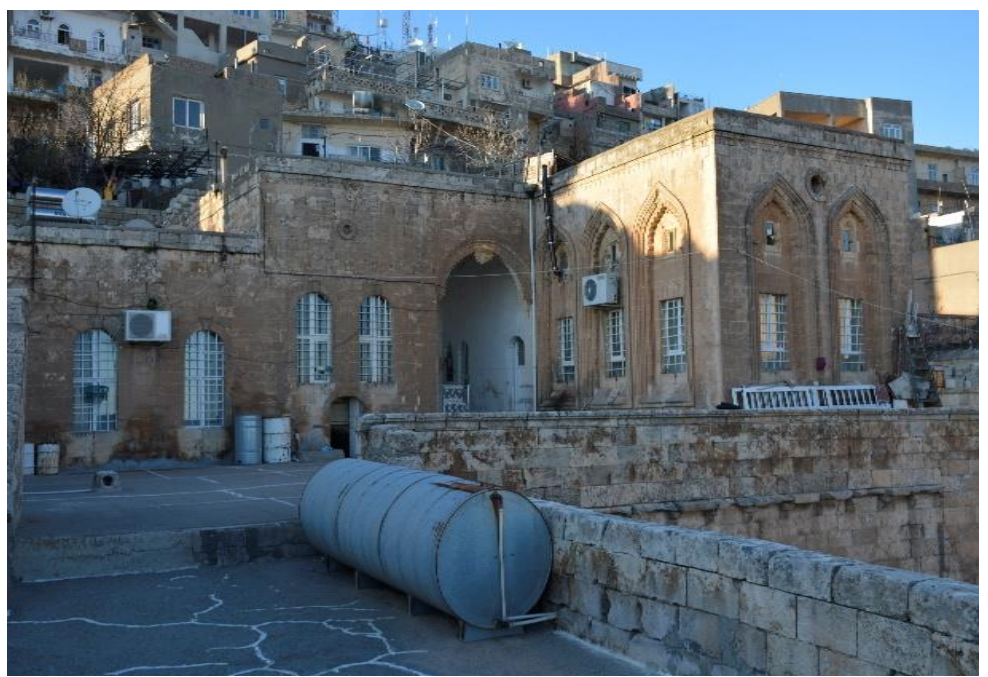

Resim 10: Emel Balamur Evi Genel görünüm (Karabulut,2019)

Eyvan etrafında üç yönde sıralı mekânlara erişim eyvan içerisinde yer alan giriş kapıları aracılığı iledir. Evyanın güneyine uzanan ve ' $L$ ' plan şemasının kısa kolunu oluşturan bölüm Başoda olarak tasarlanmış alandır (Resim 11). Başoda ortadan ikiye geniş ve dışa taşkın bir kemer ile iki birime ayrılmış ve çapraz tonoz ile örtülmüştür. Oda ikisi güney duvar üzerinde, üçü batı duvar üzerinde yer alan pencereler ile aydınlanmaktadır. Başoda tüm duvarları üzerinde yer alan nişler, kandil nişleri ve ortada yer alan dışa taşkın kemer yüzeyi de dâhil süsleme açısından evin en zengin bölümüdür (Resim 12-13). 


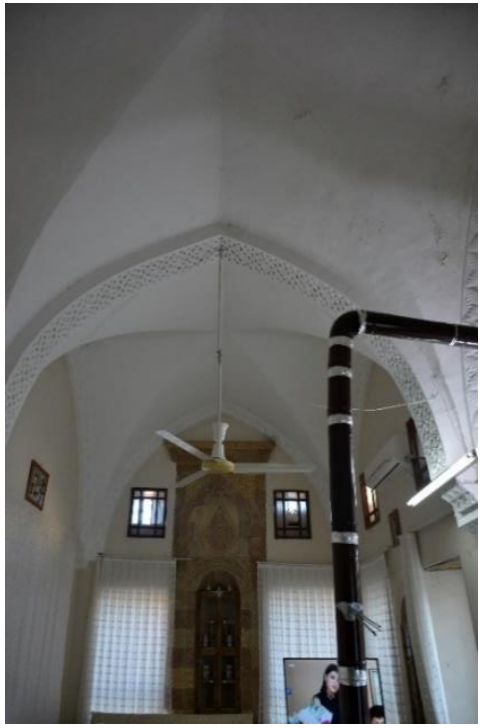

Resim 11: Emel Balamur Evi Bașoda Genel Görünüm (Karabulut,2019)

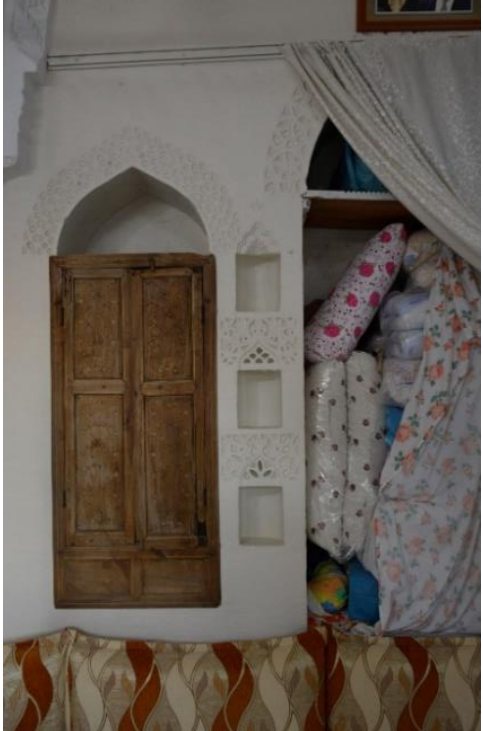

Resim 12: Emel Balamur Evi Duvar ve Nişler - Kandil Nişleri(Karabulut,2019)
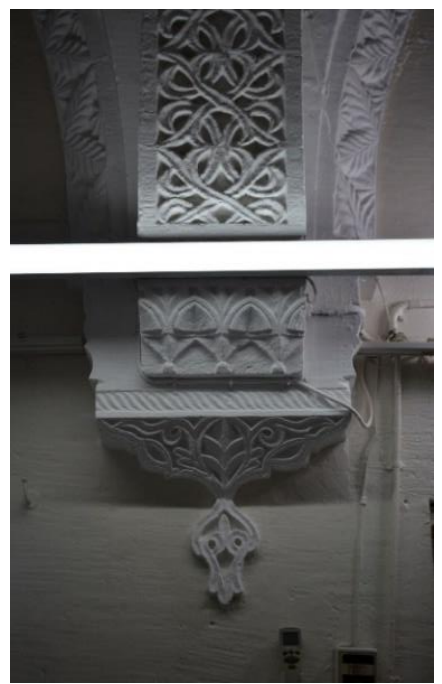

Resim 13: Emel Balamur Evi Kemer Tokası (Karabulut,2019)

\section{Mihrabiye Formlu Niş}

Başoda içerisinde en kapsamlı süsleme programına sahip alan güney duvarı üzerinde iki pencere arasında yer alan mihrabiye formlu niştir

Mihrabiye formlu niş, dikdörtgen bir görünüme sahiptir. Zeminden yaklaşık olarak $0,40 \mathrm{~cm}$ yukarıda, $3.55 \mathrm{~m}$ yükseklikte ve $1.35 \mathrm{~m}$ genişliktedir. Niş, dışarıdan içeriye doğru üç sıra bordür, yarım daire kavsara, iki yanda iki yüksek sütunçe ve sütunçeler üzerine yükselen üç kademeli sivri kemer ile en sonda bir taç kısmından oluşmaktadır (Şekil 2) (Resim 14). 


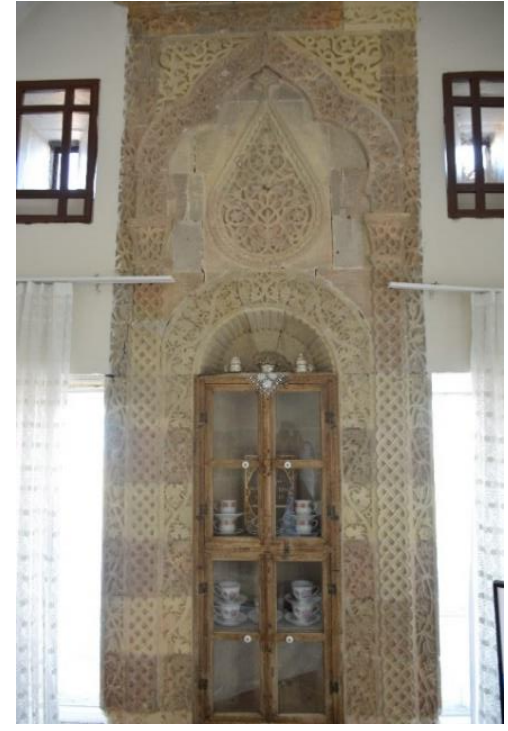

Resim 14: Emel Balamur Evi Başoda Mihrabiye Niş (Karabulut,2019)

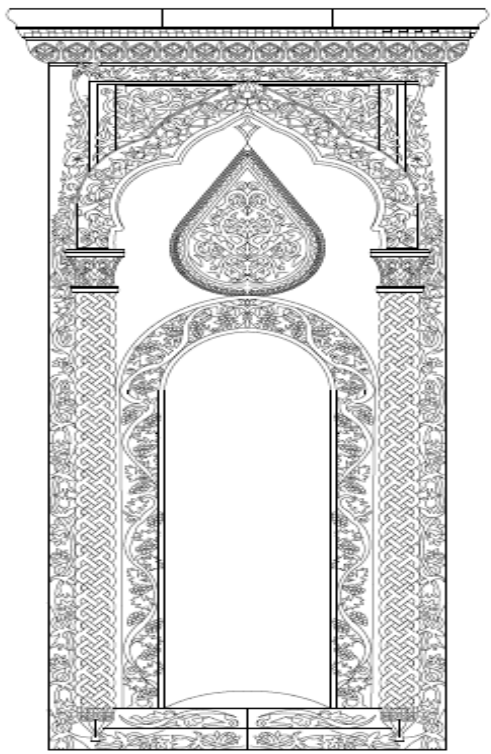

Şekil 2: Emel Balamur Evi Mihrabiye Formlu Niş Çizimi (Karabulut,2019)

Mihrabiye formlu niş derinliği $0.30 \mathrm{~m}$ 'dir. Niş kavsarası yarım daire kemerlidir. Daha içeride ise istiridye formuna sahip bir bezeme görülmektedir. Niş derinliği sonradan ahşap çerçeveli iki bölümlü bir dolap ile kapatılmıştır. Niş etrafını saran bordür ile yarım daire kemer yüzeyi kıvrım dallar arasında asma yaprakları ve üzüm salkım motifler ile bezenmiştir.

İkinci kademede bulunan hafif dışa taşkın sütunçeler $2.15 \mathrm{~m}$ yüksekliktedir. Sütünce yüzeyleri, birbirini kesen ve tekrarlardan oluşmuş geometrik şekiller ile süslenmiştir. Sütunçe başlıkları birbiri içerisine geçmiş ve uçları rumileri andıran kıvrım dalların oluşturduğu bezeme ile hareketlendirilmiştir. Sütunçe üzerine yükselen kademeli sivri kemer yüzeyi ise yine birbirini sarmalayan kıvrım dalların oluşturduğu kompozisyonla süslenmiştir.

Sivri kemer ile asıl niş arasında kalan boşlukta büyükçe bir damla motifi dikkat çekmektedir. Damla motifi boşluğu kapatacak şekilde yerleştirilmiştir. En üstte bir palmet motifi ile birleşen dış zincir içerisinde kıvrım dallar, rumiler, beş yapraklı çiçekler ve lale süslemeleri bulunmaktadır. Damla motifi içerisinde yer alan süslemelerin karmaşık halinden ziyade simetrik düzeni bir hayat ağacı motifi betimlemesini andırmaktadır (Şekil $3)$. 


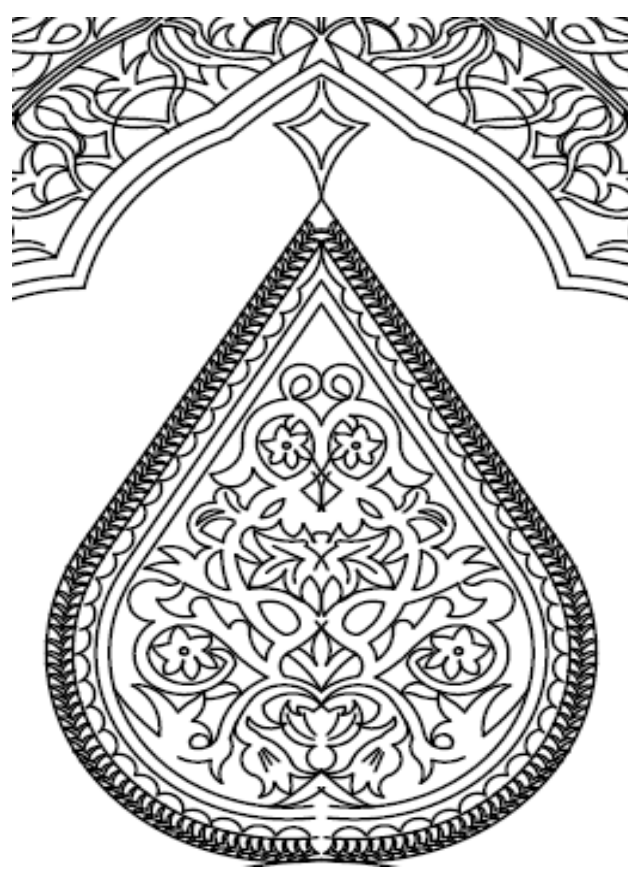

Şekil 3: Emel Balamur Evi Mihrabiye Formlu Niş Detay Çizimi (Karabulut,2019)

Nişi en dişarda ise mihrabiye formlu nişi tamamlayan ve nişi dört yandan kuşatan bordür bulunmaktadır. Bordür yüzeyi tek bir süsleme programı ile ve sivri kemerin üst bölümündeki boşlukları da dolduracak şekilde baştan sona devam etmektedir. Bordür yüzeyi birbirini tekrarlayan ve tamamlayan kıvrım dallar, bu dallar arasında lale motifleri ve yapraklar ile süslenmiştir.

Mihrabiye formlu niş en yukarıda bir taç kısmı ile son bulmaktadır. Dışa taşkın vaziyette iki kademeden oluşan taç kısmının ilk kademesi bağımsız halde rumilerden oluşan stilize bir yaprak motifi ile ard arda gelecek şekilde süslenmiştir. Daha üstte yer alan ikinci kademe yüzeyi ise küçük kare şekiller halinde oyularak hareketlilik kazandırılmıştır.

Süsleme açısından zengin bir programa sahip mihrabiye formlu niş yapının da temel malzemesi olan düzgün kesme taşın işlenmesi ile asıl formuna kavuşmuştur.

\section{Suphi Yertüm Evi}

\section{Genel Tanım}

Konut, Çabuk Mahallesinde 52. ada ve 3. parselde yer almaktadır. İki katlı müştemilatlı kâgir ev statüsünde Mardin Müzesi tarafindan yapılan çalışmalar ile tescilli yapılar listesine 2011 yılında alınmıştır.

Yap1 üzerinde herhangi bir inşa kitabesine rastlanılmamıştır. Yapı inşa malzemesi, inşa teknikleri esas alınarak yapılan değerlendirmeye göre 19. yüzyıl başlarında inşa edildiği anlaşılmaktadır. 
Genişçe bir alan üzerine arazi şartlarına uygun olacak şekilde giriş kat dâhil iki kat olarak inşa edilmiştir. Yapıya giriş, güney cephe önünde uzanan sokağa doğru açılan anıtsal kapıdan sağlanmaktadır. Giriş kat bir avlu etrafında sıralanmış mekânlardan oluşmaktadır. İkinci kat bütün olarak 'U’ plan şemasına uygun tasarlanmıştır (Şekil 4) (Resim 15).

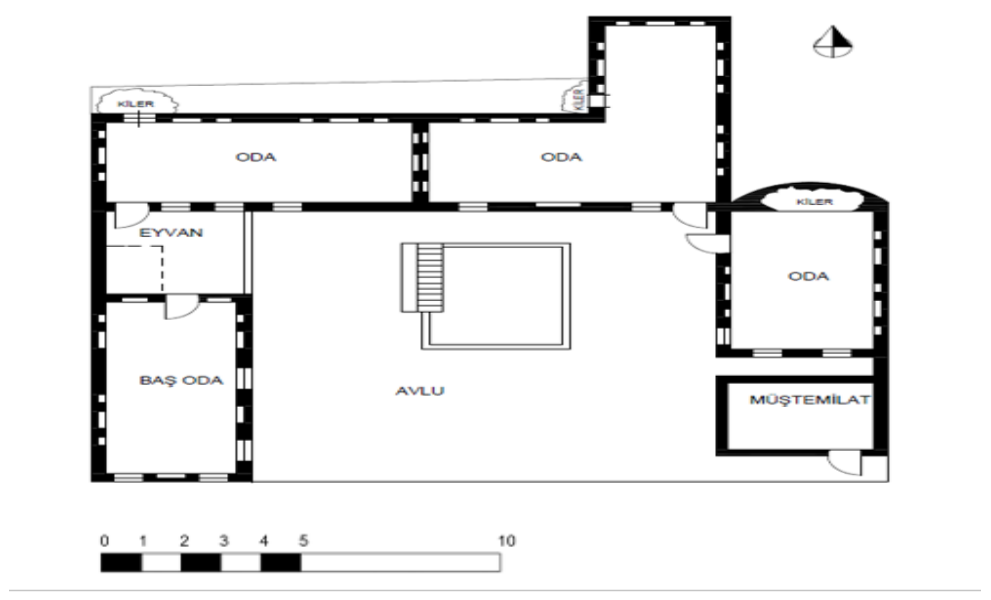

Şekil 4: Süphi Yertüm Evi Birinci Kat Planı (Karabulut,2019)

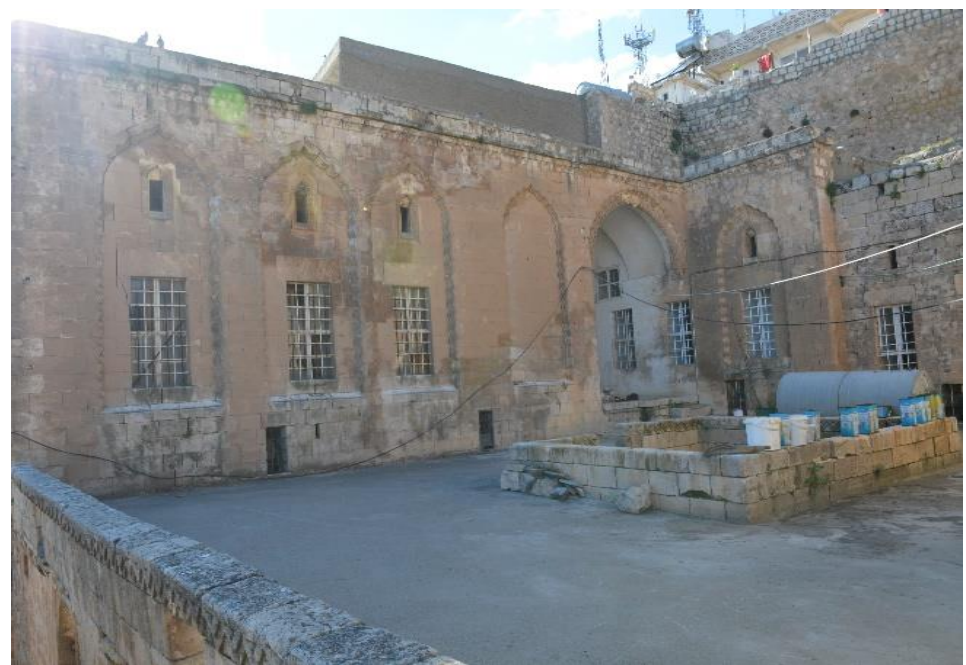

Resim 15: Süphi Yertüm Evi Genel Görünüm (Karabulut,2019)

Yapı inşa edildiği tarihten itibaren asıl amacına uygun olarak kullanılmaya devam etmiştir. İki katlı ve birçok kapalı alana sahip yapının her katında farklı ailelerin ikamet ettiği mülk sahipleri tarafından ifade edilmiştir. Fakat daha sonraları yapının sadece ikinci katı yazlık ev olarak kullanılmaya başlanmış, günümüzde ise bu durum da terk edilmiştir. Araştırma konusunu oluşturan Mihrabiye formlu nişin yer aldığı başoda, evin ikinci katında bulunan terasın batı bölümünde yer almaktadır. 
Yapının ikinci katına erişim avlu ortasında duvara bitişik taş merdiven ile sağlanmaktadır. Geniş bir avlu-teras etrafında toplanan mekânlar 'U' plan şemasını oluşturacak şekilde sıralanmıştır.

Eyvan batısında yer alan kuzey-güney doğrultuda uzanan kapalı mekân Başoda olarak tasarlanmış alandır (Resim 16). Başoda ikiye geniş ve dışa taşkın sivri kemer ile birime ayrılmıştır. Oda çapraz tonoz ile örtülmüş, ikisi güney duvar üzerinde, dördü ise doğu duvar üzerinde yer alan pencereler ile aydınlanmaktadır. Başoda tüm duvarları üzerinde yer alan nişler, kandil nişleri ve ortada yer alan dışa taşkın kemer yüzeyi de dâhil süsleme açısından evin en zengin bölümünü oluşturmaktadır (Resim 17-18).

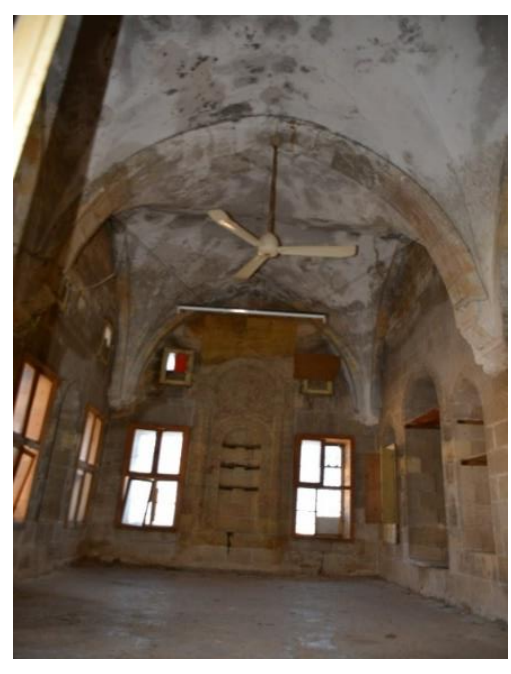

Resim 16: Süphi Yertüm Evi Başoda Genel Görünüm (Karabulut,2019)

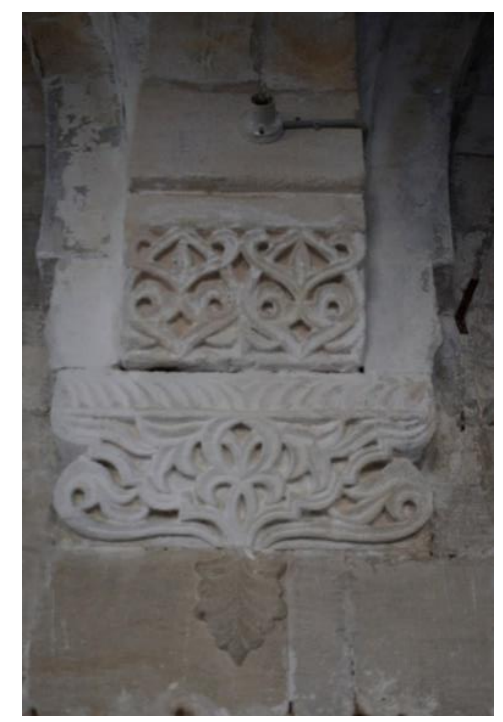

Resim 17: Süphi Yertüm Evi Kemer Tokası (Karabulut,2019)

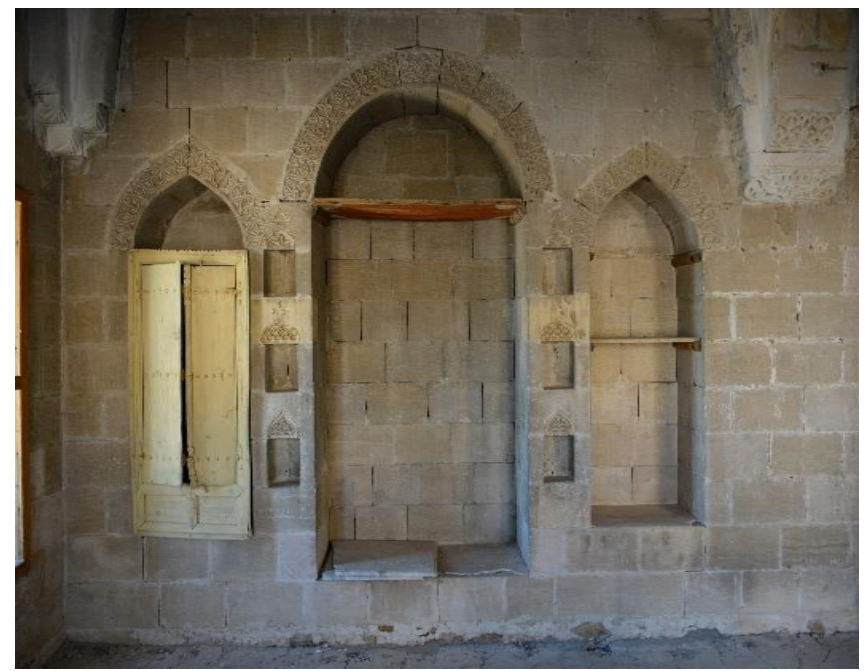

Resim 18: Süphi Yertüm Evi Başoda Duvar Nişleri (Karabulut,2019)

\section{Mihrabiye Formlu Niş}


Başoda içerisinde en kapsamlı süsleme programına sahip alan güney duvarı üzerinde iki pencere arasında yer alan mihrabiye formlu niştir.

Mihrabiye formlu niş, dikdörtgen bir görünüme sahiptir. Zeminden yaklaşık olarak 0,40 m yukarıda, $4.00 \mathrm{~m}$ yükseklikte ve $1.45 \mathrm{~m}$ genişliktedir. Niş, dışarıdan içeriye doğru üç sıra bordür, yuvarlak kemerli kavsara, iki yüksek sütunçe üzerinde birleşen yarım daire kemer ve kemer yayı içerisinde büyükçe bir madalyon, alınlık kısmını iki eşit parçaya bölen üçgen bordür, köşelerde iki rozet ve tepede bir taç kısmından oluşmaktadır (Şekil 5) (Resim 19).

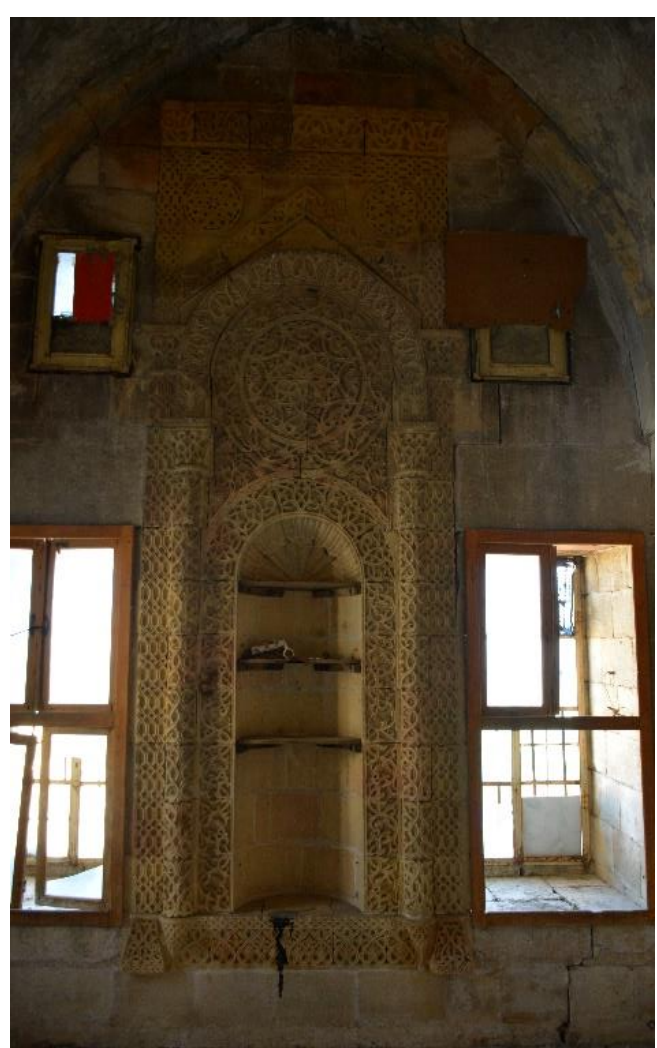

Resim 19: Süphi Yertüm Evi Mihrabiye Formlu Niş (Karabulut,2019)

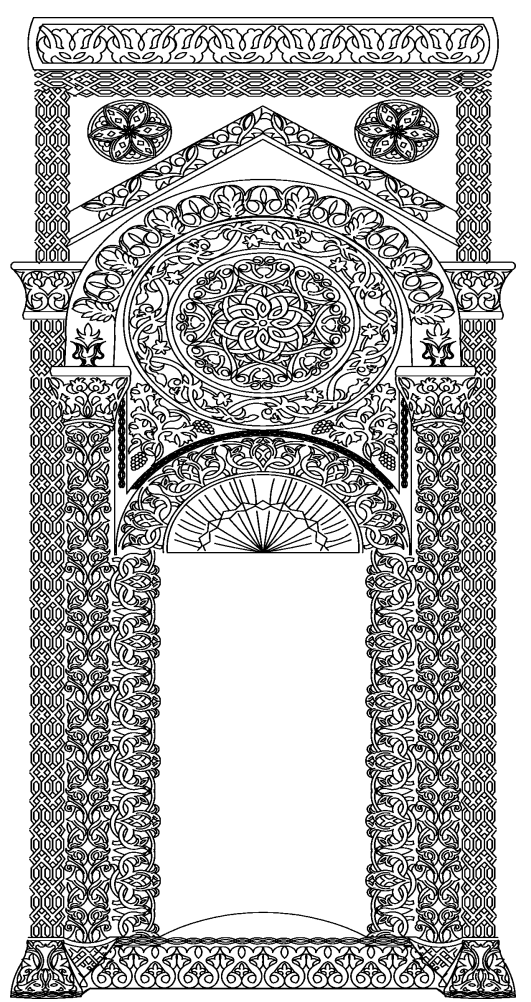

103 


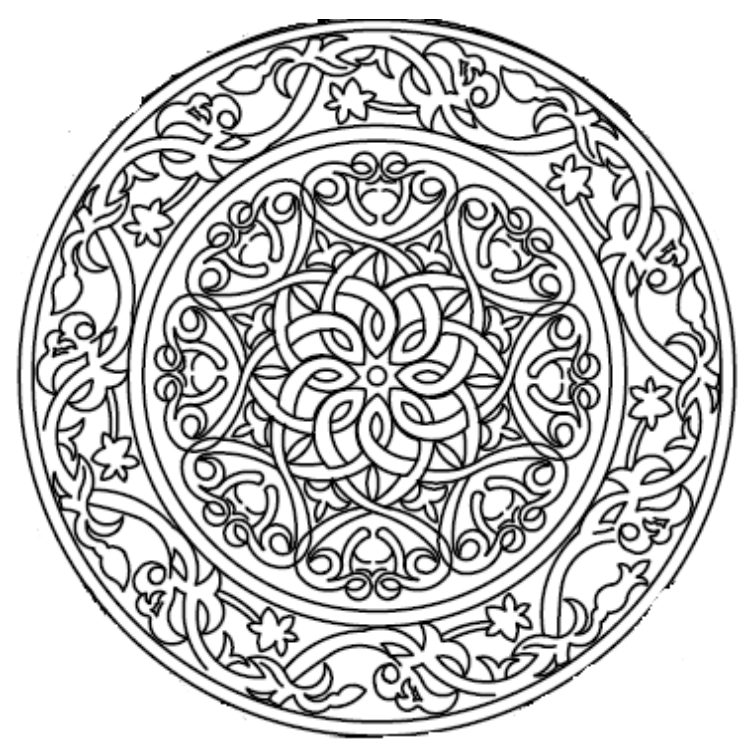

Şekil 6: Emel Balamur Evi Mihrabiye Formlu Niş (Karabulut,2019)

Mihrabiye formlu niş, en aşağıda bir sütunçe altlığı üzerine yükselen ve yüzeyi geometrik desenli bordür ile üç yönden kuşatılmış haldedir. Bu düzeni, kıvrım dallar ile beş yapraklı çiçek motifli bezemenin yer aldığı sütunçe başlı̆ğ bölmektedir.

Alınlık kısmı, madalyon üzerinde yer alan kısa bir bordür kuşağı ve bu kuşağın üzerinde iki köşede yer alan rozetlerden oluşmaktadır. Alınlık kısmında yer alan kısa bordür kuşağı üzeri rumi ve palmet desenleri ile bezenmiştir. Köşelerde yer alan rozetler ise palmetlerden oluşmuş altı yapraklı geniş bir çiçek motifi yer almaktadır.

Mihrabiye formlu niş tasarımı en üstte bir taç kısmı ile sona ermektedir. Dışa taşkın vaziyette tek kademeden oluşan taç kısmı rumiler ve palmetlerden oluşan stilize motifler yanyana getirilerek süslenmiştir.

Süsleme açısından benzerlerinde daha zengin bir programa sahip mihrabiye formlu niş düzgün kesme taşın işlenmesi ile oluşturulmuştur.

\section{Değerlendirme ve Karşılaştırma}

Konut mimarisinde odaların konum ve sayıları bütünüyle evin plan tipine etki etmektedir. Özellikle odaların konumları, diğer tüm birimlerin yayılım alanlarına etki etmektedir. Mahremiyet anlayışı ile şekillenen oda tasarımları kimlik ve statü arasındaki ilişkinin yansımasıdır. Başoda, bu bağlamda hem Anadolu hem Türk evinde içerisinde tasarım özellikler açısından en göze dikkat çeken birimdir.

Yaşam birimleri içerisinde niş olarak isimlendirilen ve kullanım mahiyetine göre boyutları değişebilen duvar yüzeylerindeki girintiler, işlevsel birer alan olarak konut mimarisinde yer almıştır. Yüklükler, dolaplar, ateşin yakılması için ocak nişleri, aydınlatma sağlamak için kullanılan kandillere ait diğer küçük girintiler ev tasarımında 
vazgeçilmez birer unsurdur. Nişlerin işlevsel birer alandan çıkıp estetik bir unsur olarak kullanılması mimari geleneğin bir parçası olduğu kadar, kimlik ve statü unsurlarının önemi ile de bağdaştırılmaktadır.

Selamlık veya Başoda olarak kullanılan evin misafir odasında zaman içerisinde değişen ve dönüşen mimari geleneğin etkisi görülebilmektedir. Duvarlar içerisinde yer alan nişlerdeki ve odanın merkezinde konumlandırılan diğer büyük nişteki süsleme programları bütünüyle nişlerin işlevsellikten kurtulup estetik bir alan olarak ortaya çıarılmış olduğunun göstergesidir. Oda içerisinde merkez konuma alınmaya çalışılmış ve boyutları ile dikkat çeken nişler, zaman içerisinde bağımsız bir tasarıma bürünerek dini mimaride kullanılan mihrap nişleri ölçeğine ulaşabilmiştir.

Diyarbakır evlerindeki niş kullanımı merkez ile taşra arasında farklılık göstermiştir. Merkezde yer alan konutlar içerisindeki nişler, özellikle dikdörtgen bir girintiden ve üç dilimli sivri kemerden ibarettir. Boyut olarak dikkat çekici bir ölçekte olmasına rağmen mihrabiye formunu taşıdıkları söylenemez. Burada süsleme malzemeye bağımlı olarak siyah bazalt taşı üzerine beyaz renkli cas teknikli bitkisel süslemelerden oluşmuştur. Nişler, işlevsel bir kullanım alanı ile beraber değerlendirilmiştir.

Ancak merkezde ve Hazro ilçesinde bulunan bazı konutlarda bu durum değişmektedir. Bey konaklarında görülen nişlerin tasarımı Mardin evlerindeki mihrabiye formlu nişlere yakın formlardır. Burada niş derinliklerinin zengin süslemeleri alçı kalıplama tekniği ile yapılmıştır. Süsleme anlayışında bir sadelik göze çarpmaktadır. Niş dikdörtgen formu içerisinde iki yanda daha ince sütunçeler ve niş derinliği içerisindeki mukarnas süsleme ile hareketlendirilmişlerdir. Niş derinliği içerisi ise çoğu zaman birer çelenk düzenini andıran alçı kabartma bitkisel süslemeler ile bezenmiştir. Ayrıca nişlerin oda içlerindeki konumları da Mardin evlerindeki konumlarından farklıdır.

Doğu Anadolu bölgesinde Erzurum evlerinde de Başoda evin merkezinde yer almıştır. Burada yine tasarımda ön planda olan odanın iç tezyinatı tavan süslemelerinden başka çiçeklik olarak anılan nişlerde yer almaktadır. Nişler odanın giriş kapısı üzerinde yer alan duvar üzerine konumlandırılmışlardır. Daha derin ve geniş bir derinliğe sahip bu nişler tasarım olarak çeşitlilik göstermektedir. Mardin evlerinde belirgin olarak karşılaşılan dikdörtgen forma Erzurum evlerinde rastlanılmamaktadır. Süslemeler genel itibari ile kalem işidir. Renkli kalem işi tekniği ile yapılmış bitkisel süslemeler daha ağırlıktadır. Yapı malzemesinin taş olarak kullanıldığı Erzurum evlerindeki niş tasarımlarında ahşap ve alçı malzeme tercih edilmiştir. Malzeme ve teknik ile süsleme anlayışlarındaki farklılıklar bu nişler üzerinde çok net bir şekilde okunabilmektedir.

Yine Orta Anadolu'da Talas evlerinde de başoda içerisindeki nişler, batı veya doğu duvarında yer almaktadır. Burada nişler, çevresindeki ahşap duvar ve dolap dekorasyonu ile bir bütünlük olacak şekilde tasarlanmışlardır. Şerbetlik olarak anılan bu nişlere ait süslemeler ise barok ve rokoko tarzındadır. Nişlerin hemen iki yanında gilveler yer almaktadır. Gilvelerin nişler ile bir bütün oluşturacak şekilde tamamlayıcı ahşap malzemeden yapıldıkları görülmektedir. Niş tasarımının anıtsal bir forma bürünmesindeki bu tamamlayıcı unsurlar Mardin evlerindeki benzerlerinde yoktur. Mardin evlerindeki nişler bütünüyle bağımsız bir form oluşturmuştur ve malzeme ile süsleme bütünüyle sarı kalker taşının kullanımı ile ortaya çıkmıştır. 
Karşılaştırılan örneklerde yapı malzemesi genellikle taştır. Kolay işlenebilir olmasından dolayı Mardin evlerinde kullanılan sarı kalker taşı aynı zamanda işlenebilirliği açısından süslemeye elverişlidir. Bu durum özellikle mihrabiye formlu nişlerin süsleme programında ikinci bir malzeme tercihini sınırlandırmıştır.

Diyarbakır, Erzurum ve Talas evlerinde bulunan nişlerde malzeme her ne kadar taş olsa da tamamlayıcı olarak alçı veya ahşap malzeme tercih edilmiştir. Özellikle Diyarbakır evlerindeki nişler alçı ve cas'tan elde edilen malzemeler ile şekillenmiştir. Erzurum ve Talas evlerinde ise nişler kısmen ahşap malzeme ile yapılmıştır. Bazen ise asıl nişi tamamlama amaçlı dekoratif ahşap malzeme kullanılarak bütünlük ve anıtsallık ortaya çıkarılmıştır.

Mihrabiye formlu nişlerde genel itibari ile bitkisel süslemeler yer almaktadır. Çoğunluk ile niş derinliğinde veya niş kemer yayı üzerinde yer alan süsleme programı Erzurum ve Talas evlerinde kalem işlerinden oluşmaktadır. Diyarbakır evlerinde ise süsleme alçı ve cas malzeme ile şekillenmiştir. Ancak Mardin evlerindeki mihrabiye formlu nişlerde süsleme programı daha geniş bir alanı kaplamakta, bütünüyle taş malzemenin işlenmesi sonucuyla ortaya çıkmıştır.

Konut mimarisinin işlevsel bir ögesi olarak oda içlerinde yer alan nişlerin zaman içerisinde bir estetik öğe haline bürünmesi, Anadolu'daki evlerin kendi mekân arayışının bir sonucu olarak görülebilmektedir. Bu arayış oda içerisinde basit açıklıkların dönüşümü ile mihrap formuna yaklaşarak mihrabiye formlu nişler ile tamamlanmıştır. Anadolu Türk evinde daimi olarak karşılaşılan niş kullanımı farklılık göstermekle beraber özgün bir form oluşturmaktan uzaktır. Ayın bölge aynı şehir içerisinde bulunan konutlarda dahi belirli bir form yer almamaktadır. Yalnız Mardin evlerinde Kuzey Suriye'de Tel Halef'teki eski yerleşim yeri kalıntılarından taht odası plan etkisinin sivil mimariye yansımış hali başoda tasarımında görülebilmektedir. Taht odası anlayışı ile başodaya dönüşen özenli oda nişlerinin bezemesel ve estetik tasarımları dikkat çekmektedir.

\section{SONUÇ}

Geleneksel konut mimarisinin ortaya çıkardığı Türk ev tipinin ayrılmaz parçası başodadır. Farklı bölgelerde gelişen çeşitli plan tiplerinde konumu değişen başoda, Mardin evlerinde güney yamaca dönük olarak inşa edilmiş 'manzara odası' olarak en büyük ve gösterişli odadır. Tezyinat olarak zengin bir süsleme programına sahiptir. Başoda tasarımının ve süsleme programının ayrılmaz bir parçası ise mihrabiye formlu nişlerdir.

Mardin Dini mimarideki mihrap nişleri örneklerinden, form ve süsleme anlayışından daha zengin örnekler Mardin evlerindeki mihrabiye formlu nişlerde özgün olarak yer almaktadır. Yapı inşa edilirken tasarlanan mihrabiye formlu nişler odanın genel süsleme programını etkileyen detayları ile odanın merkezi konumunda ve güney cephe duvarı üzerinde konumlanmıştır.

Mardin'de statü ve kimlik göstergesinin baskınlığı mimari alanda kendini konut içi süslemede hissettirmiştir. İşlevsel olarak dini mimarideki mihrap ile herhangi bir ortaklığı 
bulunmayan mihrabiye formlu nişler asıl olarak başodanın önemini ortaya çıarma amacını taşımaktadır. Barındırdığı süsleme kompozisyonu odanın bütünündeki estetik değerin odak noktasını oluşturmaktadır. Dini mimarideki mihraplar ile biçimsel ve kısmen bezemesel benzerlikler asıl olarak mimari geleneğin konut içindeki yansımaları olarak görülmektedir.

Oda içerisinde bağımsız gibi görünen fakat klasik mihrap düzeni ile benzerliklere sahip mihrabiye formlu nişler, malzeme ve teknik olarak Mardin mimari geleneğinin özelliklerini yansıtmaktadır. Süsleme programının içerdiği detaylar yine bölgenin geleneksel süsleme anlayışını yansıtmaktadır.

Anadolu'nun farklı bölgelerindeki konut mimarisine bakıldığında Mardin'deki konutlarda mihrabiye nişlerinin özenle tasarlandığı anlaşılmaktadır. Sahip olduğu form ve süsleme anlayışı ile mihrabiye formlu nişler Mardin Evlerine özgü geleneksel mimari anlayışın bir parçası olarak karşımıza çıkmaktadır.

\section{KAYNAKÇA}

Akın, G. (1989). Doğu ve Güneydoğu Anadolu'daki Tarihsel Ev Tiplerinde Anlam. Yayımlanmamış Doktora Tezi. İstanbul: İstanbul Teknik Üniversitesi, Fen Bilimleri Enstitüsü.

Alioğlu, F. (1989). Geleneksel Mardin Şehir Dokusu ve Evleri Üzerine Bir Deneme. Yayımlanmamış Doktora Tezi: İstanbul Teknik Üniversitesi, Fen Bilimleri Enstitüsü.

Aliyeva, A. (2017). Mardin ve Çevresini İçine Alan Türk Devletleri Tarihi, Makalelerle Mardin I Tarih Coğrafya, Mardin: s.267-275.

Artuk, İ. (1944). Mardin Artukoğulları Tarihi, İstanbul: Gençler Kitabevi.

Baş, G. (2010). Diyarbakır'daki Geleneksel Konut Mimarisindeki Süsleme Anlayışı, History Studies, C.2, S.2,s. 311-338.

Çerme, T. (2000). Taşç1lık ve Zanaatı ve Mimarisiyle Mardin Şehri. Tarih ve Toplum, A ğustos, İstanbul: İletişim Yayınları.

Çakmak, Ş. (2001) Erken Dönem Osmanlı Mimarisinde Taçkapılar Ankara: Kültür Bakanlığı Yayınları.

Eldem, S. H. (1968). Türk Evi Plan Tipleri. İstanbul: İ.T.Ü Mimarlık Yayınları.

Erginbaş, D. (1954). Diyarbakır Evleri, İstanbul: İ.T.Ü Mimarlık Yayınları.

Göyünç, N. (1991). XVI. Yüzyılda Mardin sancă̆g. Ankara: Türk Tarih Kurumu Basımevi.

İmamoğlu, V. (2006). Geleneksel Kayseri Evleri. Kayseri: Kayseri Büyükşehir Belediyesi Yayınları.

Karabulut, İ. H. (2019). Tarihi Mardin Evlerinin Başoda Geleneği. Yayımlanmamış Yüksek Lisans Tezi, Van: Yüzüncü Yı1 Üniversitesi Sosyal Bilimler Enstitüsü.

Karpuz, H. (1989). Erzurum Evleri, Ankara: Kültür Bakanlığı Yayınları. 
(1979). Erzurum Evleri'nin Türk İslam Mesken Mimarisindeki Yeri, Yayımlanmamış Doktora Tezi, Erzurum: Atatürk Üniversitesi Sosyal Bilimler Enstitüsü.

Korkut, D. (2019). Geleneksel Anadolu Konut Mimarisinde Talas Örneği, Yayımlanmamış Doktora Tezi, İstanbul: İstanbul Teknik Üniversitesi Fen Bilimleri Enstitüsü.

Kuban, D. (1995). Türk 'Hayat'lı Evi. İstanbul: Eren Yayınc1lı.

Küçükerman, Ö. (1985). Kendi Mekân Arayışı İçerisinde Türk Evi, İstanbul: Türkiye Turting ve Otomobil Kurumu Yayınları.

Sağlam, T.(2019).Geleneksel Erzurum Evleri: Restorasyonlarl ve Ev Yaplst. Yayınlanmamış Doktora Tezi, Erzurum: Atatürk Üniversitesi, Sosyal Bilimler Enstitüsü,

Sözen, M. \& Tanyeli, U. (2011). Sanat Sözlüğü. İstanbul: Remzi Kitabevi.

Tuncer, O. C. (2015). Diyarbakır Evleri. Diyarbakır: Diyarbakır Büyükşehir Belediyesi Yayınları.

Ünlüdil, S. (2018). Talas Evleri, Kayseri: Erciyes Üniversitesi Sosyal Bilimler Enstitüsü. 